\title{
The Effectiveness of Instagram Filter To Improve Students' Vocabulary
}

\author{
Aisyah Noor Auly ${ }^{*}$, Theresia Cicik Sophia Budiman², Faiza Hawa ${ }^{3}$ \\ ${ }^{1}$ Universitas PGRI Semarang \\ 2,3 Universitas PGRI Semarang \\ 11aisyahnoorauly@,gmail.com, ${ }^{2}$ ciciksophia@upgris.ac.id, ${ }^{3}$ faizahawa@ upgris.ac.id.
}

\begin{abstract}
Vocabulary becomes an important aspect to learn because it is the tool to recognize words' meaning and sentences, and to create sentences, paragraphs and texts. In order to improve students' vocabularies, media are needed to help students memorize them. The aim of the research is to notice how effective Instagram filter in enhancing students' vocabulary comprehension. For this reason, teacher should find an innovative media for teaching vocabulary to students in most interesting way. Lately, Instagram becomes the most widely used social networking platform. Most people spend a lot of time scrolling on Instagram just to have fun, find some information, or even to get new friends. This platform is served with feed, stories, reel, IG TV and IG filter. This study employed IG filter to be used as a media to teach vocabulary to students. This is based on what the researchers observed that most students in schools, in this case is high school, like to play with Instagram filters. This what makes the researchers interested in using Instagram filter as a media for teaching vocabularies. This research is designed as quasi experiment which is held in one of senior high schools in Jepara. The findings reveal that IG filter is effective and successful to be used as a media for teaching vocabulary and to improve students' comprehension in vocabulary. The average score was in good category (86.33). While the $\mathrm{N}$-gain score was $58.72 \%$ which is categorized as quite effective. It means that Instagram filters is quite effective as a learning media.
\end{abstract}

Keyword: Vocabulary mastery, Instagram, Instagram Filter

\section{INTRODUCTION}

English is a global language that is very important to us. As a language, English, plays its essential role in global communication (Ahmadi, 2018). Society employed English to connect and build network globally. Agca \& Özdemir (2013) stated that in today's world, it is crucial to know at least one foreign language. In recent years, the value of learning English, as a communication media, has increased. English is learnt from elementary to university level in Indonesia. Due to this importance, English is already applied all levels of education in Indonesia. In Indonesian education curriculum, the major point for learning English is to be skilful in communicating both in spoken and written. This means student should be able to communicate by using English because language is a mean of communication (Ilinawati \& Dharma, 2019).

In fact, there is a gap between what is expected and reality in class activities. The students are difficult to learn English and they could not communicate well because of the vocabulary shortage. This fact is supported by Kweldju (2004) and Priyono (2004) cited in Aisyah (2017) who found that the most significant barrier to learning English in an EFL context is the lack of vocabularies. In order to communicate well, students should have rich vocabularies. Başoğlu \& Akdemir (2010) stated that the basic step in learning a foreign language is to learn vocabulary. Furthermore, Ilinawati \& Dharma (2019) stated that the student should study vocabulary as a basic communication tool to aid in the mastery of English skills. 
Vocabulary becomes an important aspect to learn because we can understand the meaning of words, sentence and we can arrange sentences in the form of spoken or written. By doing so, students can listen, speak, read, and write in English when they have rich vocabularies. In addition, Betti and Al-Jubouri (2015:175) stated that the aim of teaching vocabulary is student should be able to: (i) when used writing or speaking, the students could spell and pronounce the words well (ii) when you hear or read a word, you should be able to recognize its meaning, (iii) recognize the correct collocation as well as its meanings or expressions, (iv) know the contexts in which happens, the relationship between interlocutors, and the medium of conversation - spoken or written and use language that is appropriate for the grammatical sentence or utterances. Mukuan (2016:75) cited in Malik \& Muhammad (2018) stated that the method or model used by the teacher or educator in the classroom can also reveal the level of success of students in learning.

For this reason, lectures require an innovation in learning media that allows students to study and practice outside of class without the assistance of a lecturer (Prastiwi \& Kinanti: 2021). In another words, the use of learning media is to help students memorizing the new vocabulary. Zheng (2012) also stated that word learning is aided by vocabulary learning tools and for the language learning process to be effective, students must be taught how to employ proper word learning tactics. Students in Indonesia learns vocabulary through their class activities in the school. They learn English vocabulary traditionally; the teacher uses printed teaching sources like a textbook. Students does not learn vocabulary outside of the class activities at the school. To overcome this, student needs media that makes them learning vocabulary easily wherever and whenever they want or the media that facilitate student to learn vocabulary independently. Learning media can elicit new desires and interests, inspire and enhance learning activities, and have psychological effects on pupils when used in the classroom (Indriyani: 2019 cited in Prastiwi \& Kinanti: 2020).

In this era of globalization, the growth of the technology is as fast as the growth of social media. This is beneficial for people to build social network and to get in touch with others whenever and wherever they want to. This makes people's life easier to link to others without having direct face to face meeting. In addition, people can find and share any kinds of information to or from the internet or from social media. Due to the increasing demand on the platform of social media, some researches are performed to know the usage of social media for educational purpose. Some studies focus on digital application for teaching and learning foreign languages (Chawinga, 2017a, 2017b; Krutka \& Carpenter, 2016; Manca \& Ranieri, 2016; O'Keeffe, 2016; Tang \& Hew, 2017) cited in Erarslan, (2019). Students, being digital natives, anticipate creative means of learning in addition to traditional modes of learning, which is why social media is used as an educational tool (Taskiran et al., 2018 cited in Erarslan: 2019). Also, scholars feel that implementing such technology into language classrooms has the capability to advance a variety of pedagogical challenges, such as teachers' inadequate time in relation to the high number of students (Cardoso \& Collins, 2016; Roblyer: 2003 cited in Aloraini: 2018). Sivagnanam \& Yunus (2020) stated that in education social networking has an important part, especially for young learners who stick to social media since the beginning of its emergence.

Then, According to Lasmiasih (2019), teenagers, particularly students, are affected by the popularity of social media. Students download the social media in their electronic devices such as computer, laptop and mobile phone to socialize via online by sharing text, photos, and videos continuously.

From the explanation above, the researchers tried to use social media as a platform for educational purpose. The researchers chose Instagram as learning media. According to statistical data by Berita Satu news, Instagram takes the 3rd position of the popular media social that used by everyone in Indonesia. The statistical data shows that almost $85 \%$ of people have an Instagram account. Instagram becomes the biggest social media that is used by everyone. Instagram has developed a filter option that, in addition to modify the colour of a photo, it also carries Augmented Reality to the picture (AR). Augmented reality is an enhanced image of physical world accomplished through the existence of contents (digital and virtual) provided by technology. Released in August 2019, the spark AR application allows people to build free 
AR filters and use them online on Instagram (Karundeng: 2020). It is a chance for teachers to make Instagram filter as media to learn vocabulary. Teachers can employ the quiz filters for enhancing students' comprehension on vocabularies.

\section{RESEARCH METHODOLOGY}

This research employed quasi experimental concentrating on one design of non-equivalent. Quasi experimental compares more than one different treatment for therapy effects assessment (Reichardt, 2019:3). This is illustrated as follows:

\begin{tabular}{|lll|}
\hline $\mathrm{O}_{1}$ & $\mathrm{X}$ & $\mathrm{O}_{2}$ \\
\hline $\mathrm{O}_{3}$ & $\mathrm{O}_{4}$ \\
\hline
\end{tabular}

(Reichardt, 2019:115)

In the table above, $\mathrm{O} 1$ to $\mathrm{O} 4$ and $\mathrm{X}$ are presenting the names of the groups involved in this research. O1 represents pre-test of experimental group, $\mathrm{O} 2$ is for post-test of experimental group, $\mathrm{O} 3$ is for pre-test of control group, and last $\mathrm{O} 4$ represents post-test of control group. The single $\mathrm{X}$ is treatment. Those two groups, experimental and control, were given pre-test.

The research was done in one high school in Jepara Central Java. The eleventh-grade students were taken as the population with the total number of 252 students. Random cluster sampling was employed by taking two classes consisted 36 students each. The data of this research were taken from pre and post-test. The treatment employed Instagram Filter as media for experimental class and teacher-centered teaching is for the control class. Figure 1 below served the concept of Instagram Filter as a media to comprehend vocabularies.

Figure 1. Concept of Instagram Filter

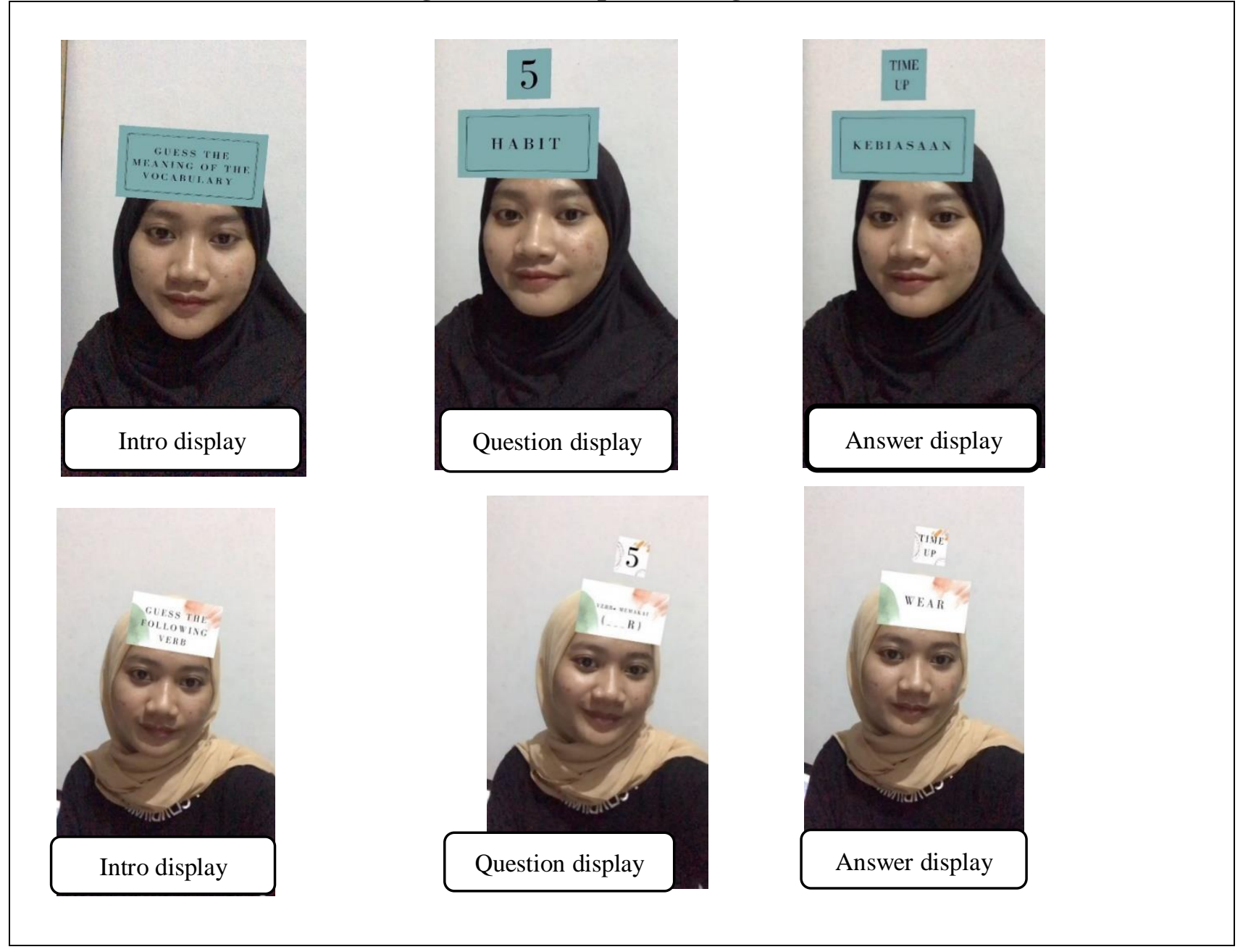


Spark AR application helped the researchers in forming the Instagram filter. The researchers propose the IG filters to the spark AR reviewer for approval. The reviewer of the spark AR reviewed the content of the proposed filter to assure that it met the required requirements. This Instagram filter evaluation took one day (Karundeng, 2020). The Instagram Filter can be accessed in Instagram account @aisyahnoorauly.

After collecting the data, the researchers analyzed the results to know the students' improvement in comprehending vocabularies when they were taught with and without Instagram filter as the learning media. The researchers took four steps to analyze the test result. First, the researchers gave the test to students. Second, the researchers scored the test. Third, the researchers analyzed the result of the test. The data analysis involved five steps namely; descriptive statistical test, normality test, homogeneity test, hypothesis test, Normalized gain score. Fourth, the researchers concluded the results by using statistical formula.

\section{RESULTS AND DISCUSSION}

\section{Students' Vocabulary Mastery before Taught Using Instagram Filter}

The aim of this study is to know how effective Instagram filter to be used as a media for teaching vocabulary. This research took place in one public senior high school Jepara Central Java. In conducting this research, two groups were involved, namely experiment and control group. There were 36 students available in each group. Researchers gave students of both classes pre-test at the early meeting. The pre-test consisted of 25 questions on multiple choice and jumbled words. Pre-test was given to know the students' score in doing the test without using the IG filter in their learning process. After getting the result of pre-test score, the researchers clustered the scores into some categories that can be seen in table 1 below.

Table 1 The total grade of pre-test in control class

\begin{tabular}{|l|l|l|l|}
\hline $\begin{array}{l}\text { Students } \\
\text { score }\end{array}$ & Grade & $\begin{array}{l}\text { Number of } \\
\text { students }\end{array}$ & Category \\
\hline $\mathbf{9 0}-\mathbf{1 0 0}$ & A & 0 & Excellent \\
\hline $\mathbf{8 0}-\mathbf{8 9}$ & B & 7 & Good \\
\hline $\mathbf{7 0}-\mathbf{7 9}$ & C & 5 & Adequate \\
\hline $\mathbf{6 0}-\mathbf{6 9}$ & D & 13 & Unsatisfactory \\
\hline $\mathbf{0}-\mathbf{5 9}$ & E & 11 & Unacceptable \\
\hline
\end{tabular}

For the experimental class, the researchers got the scores of pre-tests and then categorized them into the categories below in table 2 .

Tabel 2 The total grade of pre-test in experiment class

\begin{tabular}{|l|l|l|l|}
\hline $\begin{array}{l}\text { Students } \\
\text { score }\end{array}$ & Grade & $\begin{array}{l}\text { Number } \\
\text { students }\end{array}$ & Category \\
\hline $\mathbf{9 0}-\mathbf{1 0 0}$ & A & 0 & Excellent \\
\hline $\mathbf{8 0}-\mathbf{8 9}$ & B & 9 & Good \\
\hline $\mathbf{7 0}-\mathbf{7 9}$ & C & 10 & Adequate \\
\hline $\mathbf{6 0}-\mathbf{6 9}$ & D & 11 & Unsatisfactory \\
\hline $\mathbf{0}-\mathbf{5 9}$ & E & 6 & Unacceptable \\
\hline
\end{tabular}

Table 3 below showed the results of the mean score for pre-test of both control and experiment class. 
Table 3 Descriptive Statistic of Pre-Test Control Group and Experiment Group

\begin{tabular}{ll|l|l|l|l} 
& N & Minimum & Maximum & Mean & Std. Deviation \\
\hline Pre-Test Control & 36 & 40 & 88 & 63.22 & 14.047 \\
\hline Pre-test Experiment & 36 & 40 & 88 & 69.44 & 11.360 \\
\hline Valid N (listwise) & 36 & & & & \\
\hline
\end{tabular}

Pre-test mean are portrayed based on the table of the following categories in order to establish the level of students' achievement. From the table below, the researchers categorized the students score based on Brown (2004).

Tabel 4 Students' score category

\begin{tabular}{|l|l|l|}
\hline Students' score & Grade & Category \\
\hline $90-100$ & A & Excellent \\
\hline $80-89$ & B & Good \\
\hline $70-79$ & C & Adequate \\
\hline $60-69$ & D & Unsatisfactory \\
\hline $0-59$ & E & Unacceptable \\
\hline
\end{tabular}

From the table 3 above, it can be noticed that the mean score of experimental groups is 69.44 and it belongs to unsatisfactory category. Then, the average score of control group is 63.22 and it is considered as unsatisfactory. The pre-test result showed that the students' improvement in comprehending vocabularies from the experiment and control group stayed in the same range of category.

\section{Treatment}

The next procedure was the researchers gave treatment to control and experiment class at the second meeting. The control group was given treatment by asking them to guess the meaning of some vocabularies. Then, the researchers asked them to find the answers in the dictionaries. While for the experiment class, the researchers provided treatment to students by using Instagram filter as the learning media. Students should answer some questions in the Instagram filter. The students were very active when they used the Instagram filter, as it is proven by seeing their enthusiasm when answering the questions.

\section{Students' Vocabulary Mastery after Taught Using Instagram Filter}

After giving the pre-test and treatment, the post-test is given to both classes. Multiple choice and jumbled words test were shared to students for the post-test. The test was in total 25 number for both kinds of questions. The aim of this test is to gauge students' vocabulary mastery after they were taught using Instagram Filter as the media and taught without Instagram Filter as the media. The post-test is used to compare the students' results in pre-test and post-test. Post-test was done to seek some information related to students' scores whether the students' results remained the same, were increased, or were decreased. Table 5 below is the categorization for the scores gotten from the post-test done to control class. 
Tabel 5 The total grade of post-test in control class

\begin{tabular}{|l|l|l|l|}
\hline Students score & Grade & $\begin{array}{l}\text { Number } \\
\text { students }\end{array}$ & of \\
\hline $\mathbf{9 0}-\mathbf{1 0 0}$ & A & 5 & Excellent \\
\hline $\mathbf{8 0}-\mathbf{8 9}$ & B & 10 & Good \\
\hline $\mathbf{7 0}-\mathbf{7 9}$ & C & 10 & Adequate \\
\hline $\mathbf{6 0}-\mathbf{6 9}$ & D & 8 & Unsatisfactory \\
\hline $\mathbf{0}-\mathbf{5 9}$ & E & 3 & Unacceptable \\
\hline
\end{tabular}

Table 5 served the results of total grade post-test from control group. 5 students were listed A, 10 students were listed B and C, 8 students listed as C, and only 3 listed as E. To calculate the percentage of the students' grades, the researchers used the formulation presented below:

$P=\frac{F}{N} \times 100 \%$

The formula stated above using $\mathrm{P}$ to show the percentage of students' score. $\mathrm{F}$ is used to show the number of students who got certain score, and $\mathrm{N}$ shows total number of the students involved.

After calculating the percentage of the students' grade of post-test in control class, the results can be seen below:

Tabel 6. The percentage of the students' grade of post-test in control class.

\begin{tabular}{|l|l|l|l|l|}
\hline Students score & Grade & Number of students & Category & Percentage \\
\hline $\mathbf{9 0}-\mathbf{1 0 0}$ & A & 5 & Excellent & $13.9 \%$ \\
\hline $\mathbf{8 0}-\mathbf{8 9}$ & B & 10 & Good & $27.8 \%$ \\
\hline $\mathbf{7 0}-\mathbf{7 9}$ & C & 10 & Adequate & $27.8 \%$ \\
\hline $\mathbf{6 0}-\mathbf{6 9}$ & D & 8 & Unsatisfactory & $22.2 \%$ \\
\hline $\mathbf{0}-\mathbf{5 9}$ & E & 3 & Unacceptable & $8.3 \%$ \\
\hline
\end{tabular}

Then, the categorization of the total grade of post-test gotten from experimental class falls into like this:

Tabel 7. The total grade of post-test in experiment class

\begin{tabular}{|l|l|l|l|}
\hline Students score & Grade & $\begin{array}{l}\text { Number } \\
\text { students }\end{array}$ & of \\
\hline $\mathbf{9 0}-\mathbf{1 0 0}$ & A & 14 & Excellent \\
\hline $\mathbf{8 0}-\mathbf{8 9}$ & $\mathrm{B}$ & 14 & Good \\
\hline $\mathbf{7 0}-\mathbf{7 9}$ & $\mathrm{C}$ & 8 & Adequate \\
\hline $\mathbf{6 0}-\mathbf{6 9}$ & $\mathrm{D}$ & 0 & Unsatisfactory \\
\hline $\mathbf{0}-\mathbf{5 9}$ & $\mathrm{E}$ & 0 & Unacceptable \\
\hline
\end{tabular}

Table 7 displayed the results that there were 14 students in the range A and B categories, 14 students were in B category, 8 students were in C category, and none was found in D and E categories. To calculate the percentage of the students' grades, the researchers used the same formula as it was shown above. Below are the results: 
Tabel 8 The percentage of the students' grade of post-test in experiment class.

\begin{tabular}{|l|l|l|l|l|}
\hline $\begin{array}{l}\text { Students } \\
\text { score }\end{array}$ & Grade & $\begin{array}{l}\text { Number of } \\
\text { students }\end{array}$ & Category & Percentage \\
\hline $\mathbf{9 0}-\mathbf{1 0 0}$ & A & 14 & Excellent & $38.9 \%$ \\
\hline $\mathbf{8 0}-\mathbf{8 9}$ & B & 14 & Good & $38.9 \%$ \\
\hline $\mathbf{7 0}-\mathbf{7 9}$ & C & 8 & Adequate & $22.2 \%$ \\
\hline $\mathbf{6 0}-\mathbf{6 9}$ & D & 0 & Unsatisfactory & $0 \%$ \\
\hline $\mathbf{0}-\mathbf{5 9}$ & E & 0 & Unacceptable & $0 \%$ \\
\hline
\end{tabular}

The results were dominated by excellent and good category (38.9\%), and adequate (22.2\%). None of the students were in the unsatisfactory and unacceptable category. Following up the results, the researchers calculated the mean score of the post-test. They can be seen as follows.

Table 9 Descriptive Statistic of Post-test Control Group and Experimental Group

\begin{tabular}{ll|l|l|l|l} 
& N & Minimum & Maximum & Mean & Std. Deviation \\
\hline Post-test Control & 36 & 44 & 92 & 75.44 & 11.520 \\
\hline Post-test Experiment & 36 & 72 & 100 & 86.33 & 8.301 \\
\hline Valid N (listwise) & 36 & & & & \\
\hline
\end{tabular}

From the results as shown in table 9, then they were categorized as A (excellent), B (good), C (Adequate), D (unsatisfactory), and E (unacceptable). Those were taken from Brown (2014). The average score for experiment groups was 86.33 and it belongs to good category after they were taught by using Instagram filter. Then, the average score for control group was 75.44 said as adequate.

The Comparation between Students' Who Are Taught Using Instagram Filter and Who Are Taught Without Using Instagram Filter.

Counting the normality test was done to know whether the data is normally distributed or not. According to Mishra et al (2019), the normality tests can be managed using statistical software SPSS. The data is considered normal if the significant value reaches more than 0.05 ; but if it is less than 0.05 , it is abnormal.

Table 10 displayed the results of the computation in the Kolmogorov-Smirnov column.

Table 10 Normality Test

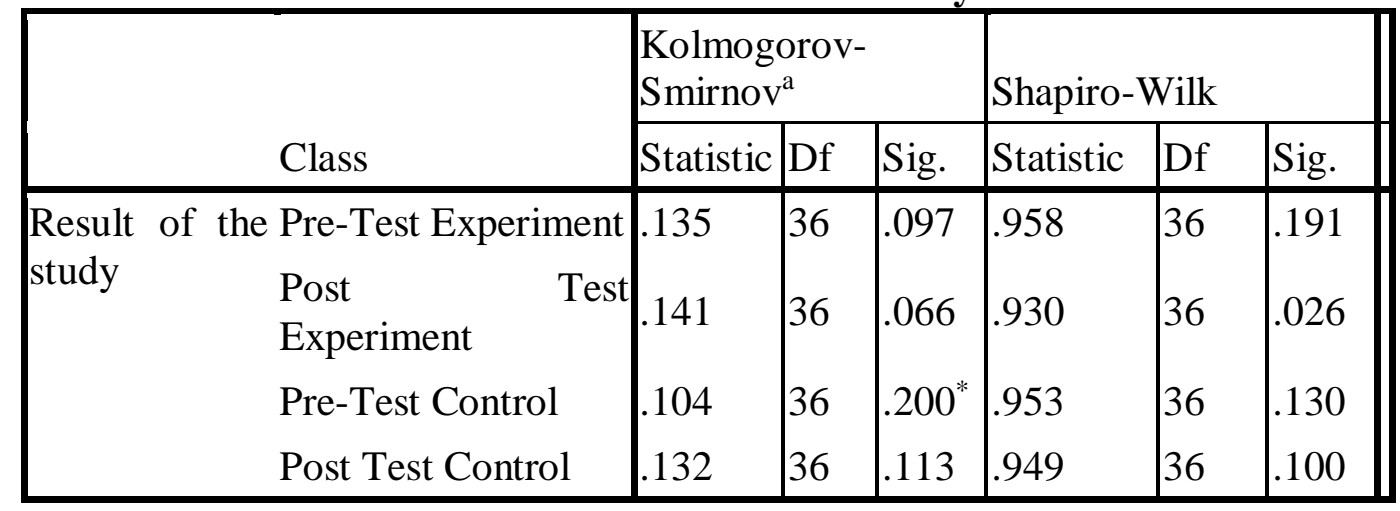

Table 10 displayed the normality test of Kolmogorov - Smirnov. It showed that significant value (sig) in pre-test for experiment class is 0.97 , and 0.66 for the post-test. The significant 
value (sig) in pre-test and post-test for control class showed the same number. It is 0.200 . those numbers indicated that the data was normally distributed.

As the next step, the researchers used the variance of homogeneity test to determine the t-test formula by examining two samples variance to see whether it is homogeneous or not (Usmadi, 2020). The foundation of decision making in the homogeneity test is shown from the significant value (sig) based on the mean. The significant value (sig) based on the mean was 0.162 which means, it is $>0.05$. The conclusion of the data is homogenous.

Table 11 Test of Homogeneity of variance

\begin{tabular}{|c|c|c|c|c|}
\hline & $\begin{array}{l}\text { Levene } \\
\text { Statistic }\end{array}$ & df1 & df 2 & Sig. \\
\hline he Based on Mean & 2.001 & 1 & 70 & .162 \\
\hline Based on Median & 1.748 & 1 & 70 & .190 \\
\hline $\begin{array}{l}\text { Based on Median and } \\
\text { with adjusted df }\end{array}$ & 1.748 & 1 & 54.762 & .192 \\
\hline Based on trimmed mean & 1.762 & 1 & 70 & .189 \\
\hline
\end{tabular}

The inequality between students' vocabulary mastery in both classes is analyzed by t-test. Kim (2015) stated that t-test functions to see the comparability of the means between the two groups. The independent sample of t-test is a kind of t-test that is being used in this research. Kim (2015) stated that t-test counting was done to find out if the differences existed between the means of two-grouped samples identical to t-test done with one-grouped sample. The basis of decision making in the hypothesis test is; If the significant value (2-tailed) $<0,05$, so the Ho is declined and the $\mathrm{Ha}$ is accepted. If the significant value (2-tailed) $>0,005$, so the Ho is accepted and the $\mathrm{Ha}$ is declined. Ho means there is no significant difference of the students' vocabulary mastery between students who are taught using Instagram filter as the media and the students who are taught without Instagram filter as the media. While Ha means there is a significant difference of the students' vocabulary mastery between students who are taught using Instagram filter as the media and the students who are taught without Instagram filter as the media.

Tabel 12 Independent Samples Test

\begin{tabular}{|c|c|c|c|c|c|c|c|c|c|c|}
\hline & \multicolumn{2}{|c|}{$\begin{array}{l}\text { Levene's Test for } \\
\text { Equality } \\
\text { Variances }\end{array}$} & \multicolumn{7}{|c|}{ t-test for Equality of Means } \\
\hline & & \multirow[b]{2}{*}{$\mathrm{F}$} & \multirow[b]{2}{*}{ Sig. } & \multirow[b]{2}{*}{$\mathrm{T}$} & \multirow[b]{2}{*}{ Df } & \multirow{2}{*}{$\begin{array}{l}\text { Sig. (2- } \\
\text { tailed) }\end{array}$} & \multirow{2}{*}{$\begin{array}{l}\text { Mean } \\
\text { Differenc } \\
\text { e }\end{array}$} & \multirow{2}{*}{$\begin{array}{l}\text { Std. Error } \\
\text { Difference }\end{array}$} & \multicolumn{2}{|c|}{$\begin{array}{l}\text { 95\% Confidence Interval of } \\
\text { the Difference }\end{array}$} \\
\hline & & & & & & & & & Lower & Upper \\
\hline $\begin{array}{l}\text { Learning } \\
\text { Result }\end{array}$ & $\begin{array}{l}\text { Equal variances } \\
\text { assumed } \\
\text { Equal variances not } \\
\text { assumed }\end{array}$ & 2.001 & .162 & $\begin{array}{l}4.601 \\
4.601\end{array}$ & $\begin{array}{l}70 \\
63.630\end{array}$ & $\begin{array}{l}.000 \\
.000\end{array}$ & $\begin{array}{l}10.889 \\
10.889\end{array}$ & $\begin{array}{l}2.367 \\
2.367\end{array}$ & $\begin{array}{l}6.169 \\
6.161\end{array}$ & $\begin{array}{l}15.609 \\
15.617\end{array}$ \\
\hline
\end{tabular}

The result of sig (2-tailed) is $000>0.05$ so the Ho is declined and the Ha is accepted. It can be concluded that there is significant difference of students who are taught using Instagram filter and students who are taught without Instagram filter.

Meanwhile, to reveal how effective Instagram filter as the learning media, the researchers analyzed the data using Normalized gain ( $\mathrm{N}$ - gain score). The formula is as follows: 
$N$ Gain $=\frac{\text { Posttest score }- \text { Pretest score }}{\text { Ideal Score }- \text { Posttest score }}$

Where: Ideal score $=100$

After getting the $\mathrm{N}$ gain score, the researchers categorized into some criterion.

Table 14 N Gain score acchievement

\begin{tabular}{|l|l|}
\hline Precentage (\%) & Grade \\
\hline$<40$ & Ineffective \\
\hline $40-55$ & Less Effective \\
\hline $56-75$ & Quite effective \\
\hline$>76$ & Effective \\
\hline
\end{tabular}

(Hake, R, R. 1999)

The result of Normalized gain proves that the Instagram filter use as the learning media is quite effective with the percentage 58. 72\%. The use of conventional method proves that the percentage is $33.20 \%$ and it means less effective. The significant difference of experimental and control class in teaching learning process reveals that Instagram filter will bring the best result in learning vocabularies. The result of the study shows the Instagram filter is quite effective for improving students' comprehension in learning vocabularies.

\section{CONCLUSION}

As the results of the research were already gained, some conclusions can be drawn. Instagram filter is designed to help students comprehending new vocabularies. The filter was created as a quiz by providing question and answer as the filter content. By using this filter, students are able to improve their vocabulary comprehension. Their improvements are related to the number of vocabularies they memorize and their ability to guess the meaning of new vocabularies. This is in line as what stated by Betti and Al-Jubouri (2015:175). They mentioned the goal of teaching vocabulary is to make students able to recognize the meaning of the vocabularies when they appear in both spoken and written communication. Some advantages of using IG filter for learning media can be noted as follows: IG filter is attractive, accessible, fun, and challenging. The more they use the filter, the more they enrich their minds with new vocabularies.

The rapid development of knowledge and technology urges everyone to be able to use it in every sector of their lives. This reason leads teachers to involve technology and social media while doing teaching and learning, in this case is Instagram, to modernize classroom atmosphere in learning. It is possible to conclude that Instagram filter is a type of media that can be used to assist teachers in delivering materials to students. This is an attractive media to trigger students' involvement in the process of teaching and learning. This media can make the learning process more appealing and fun. Instagram filter becomes a media that facilitate students to learn vocabulary outside of the class activities. Instagram filter is an innovative media to improve students' ability in mastering English, especially in mastering vocabulary.

\section{REFERENCES}

Agca, R. K., \& Özdemir, S. (2013). Foreign Language Vocabulary Learning with Mobile Technologies. Procedia - Social and Behavioral Sciences, 83, 781-785. https://doi.org/10.1016/j.sbspro.2013.06.147

Ahmadi, Mohammad Reza. (2018). The use of technology in english language learning: A literature review. International Journal of Reasearch in English Education (IJREE). 3(2). $115-125$.

Aloraini, N. (2018). Investigating Instagram as an EFL Learning Tool. Arab World English Journal, 4(4), 174-184. https://doi.org/10.24093/awej/call4.13 
Asyiah, D. N. (2017). the Vocabulary Teaching and Vocabulary Learning: Perception, Strategies, and Influences on Students' Vocabulary Mastery. Jurnal Bahasa Lingua Scientia, 9(2), 293-318. https://doi.org/10.21274/1s.2017.9.2.293-318

Başoğlu, E. B., \& Akdemir, Ö. (2010). A comparison of undergraduate students' English vocabulary learning: Using mobile phones and flash cards. Turkish Online Journal of Educational Technology, 9(3), 1-7.

Betti, Mohammad Jasim \& Chasib Fanukh. Al-Jubouri. (2015). Approaches and Methods of Teaching English as A Foreign Language. Nippur Publishing.

Brown, H. Douglas. (2004). Principles of Language Learning and Teaching. London: Longman.

Cara Menghitung N-Gain Score Kelas Eksperimen dan Kontrol dengan SPSS. Retrived September 26, 2021. from. https://www.spssindonesia.com/2019/04/cara-menghitubg-ngain-score-spss.html

Erarslan, A. (2019). Instagram as an Education Platform for EFL Learners. Turkish Online Journal of Educational Technology - TOJET, 18(3), 54-69.

Ilinawati, I., \& Dharma, Y. P. (2019). Improving Students' Vocabulary Through Songs. JEES: Journal of English Educational Study, 1(2), 66-70. https://doi.org/10.31932/jees.v1i2.329

Karundeng, F. (2020). Developing Instagram Filter-Based Accounting Educational Game As a Fun Learning Media. Review of Behavioral Aspect in Organizations and Society, 2(2), 113-130. https://doi.org/10.32770/rbaos.vol2113-130

Kim, T. K. (2015). T test as a parametric statistic. Korean Journal of Anesthology. 68(6). 540546.

Lasmiasih. (2019). The effectiveness of instagram media for teaching vocabulary at the seventh grade of SMP PGRI 1 Buayan. ELTic CONFERENCE. 4(1). 86-96.

Malik, Agung Rinaldi \& Muhammad, Nur. A. A. (2019). Using social media as a learning media of foreign language students in higher education. BAHTERA: Jurnal Pendidikan Bahasa dan Sastra. 18(2). 1-14.

Mishra, P., Pandey, C. M., Singh, U., Gupta, A., Sahu, C., \& Keshri, A. (2019). Descriptive statistics and normality tests for statistical data. Annals of Cardiac Anaesthesia, 22(1), 6772. https://doi.org/10.4103/aca.ACA_157_18

Prastiwi, A.D \& Kinanti, Resmi Hayati. (2021). Efektivitas gase android sebagai media pengajaran untuk meningkatkan kosa kata bahasa inggris di kalangan mahasiswa permesinan kapal. Tekmapro: Journal of Industrial Engineering and Management. 16(02). 25-35.

Reichardt, Charles S. (2019). Quasi-Experiment: A Guide to Design and Analysis. The Guilford Press.

Sivagnanam, S., \& Yunus, M. M. (2020). Utilizing social media in vocabulary enhancement among primary ESL learners. Universal Journal of Educational Research, 8(2), 490-498. https://doi.org/10.13189/ujer.2020.080220

Usmadi. (2020). Pengujian Persyaratan Analisis (Uji Homogenitas dan Uji Normalitas). Inovasi Pendidikan, 7(1), 50-62.

Zheng, S. (2012). Studies and suggestions on English vocabulary teaching and learning. English Language Teaching, 5(5), 129-135. https://doi.org/10.5539/elt.v5n5p129 